\title{
Anaerobic Soil Disinfestation to Manage Soilborne Diseases in Muck Soil Vegetable Production Systems
}

\author{
Anna L. Testen and Sally A. Miller ${ }^{\dagger}$ \\ Department of Plant Pathology, The Ohio State University Ohio Agricultural Research and Development Center, Wooster, \\ $\mathrm{OH} 44691$
}

\begin{abstract}
Anaerobic soil disinfestation (ASD) was evaluated as a tool for managing the root-knot nematode Meloidogyne hapla in lettuce (Lactuca sativa) and clubroot disease, caused by Plasmodiophora brassicae, in mustard greens (Brassica juncea) produced on Ohio muck soils in Huron and Stark Counties. In two consecutive years of field trials, wheat bran $\left(20.2 \mathrm{Mg} \mathrm{ha}^{-1}\right)$, molasses $\left(10.1 \mathrm{Mg} \mathrm{ha}^{-1}\right)$, and wheat bran $\left(20.2 \mathrm{Mg} \mathrm{ha}^{-1}\right)$ plus molasses $\left(10.1 \mathrm{Mg} \mathrm{ha}^{-1}\right.$ ) were assessed as ASD carbon sources and compared with nonamended controls. Data were collected from plants grown in the field and from plants grown in field-treated soils in growth chamberbased post-ASD bioassays. Anaerobic conditions developed in ASD-treated soils in both trial years, as indicated by polyvinyl chloride pipes painted with an iron oxide paint. Soil $\mathrm{pH}$ did not decrease during ASD at the Huron County site of the mustard greens clubroot trials in either trial year but soil

inconsistent in direct field measurements; however, significantly higher biomasses were observed in lettuce and mustard greens grown in bioassay soils collected from plots treated with ASD with wheat bran-based amendments compared with plants grown in soils from control plots. Based on direct field measurements and bioassays, the use of ASD with any carbon source led to significant reductions in root-knot nematode galling on lettuce compared with controls. Reductions in clubroot severity in mustard greens following ASD were less consistent; however, significant reductions in clubroot severity were observed in the field in one trial year and in both years of bioassays. The results of these studies indicate that ASD is a promising tool for managing soilborne diseases in muck soil vegetable production systems.
\end{abstract} $\mathrm{pH}$ decreased significantly during ASD in Stark County soils treated with ASD with either wheat bran or wheat bran plus molasses compared with control soils in both trial years. Impacts of ASD on plant biomass were
Keywords: cultural and biological practices, disease management, nematodes, organic soil, vegetables.
Muck soils are high organic matter-containing soils (Histosols with typically $>20 \%$ organic matter) derived from drained wetlands and are used often for high-value vegetable production in the Midwestern and Northeastern United States, including Ohio, Michigan, Indiana, Illinois, Michigan, New York, and Wisconsin, and portions of Canada, including Ontario. Leafy greens such as lettuce (Lactuca sativa) and mustard greens (Brassica juncea) are commonly produced on muck soils.

The productivity and profitability of muck specialty crops is limited by soilborne pathogens and diseases such as root-knot nematodes (Meloidogyne spp.) and clubroot (Plasmodiophora brassicae), and management of these soilborne diseases requires integrated approaches. Root-knot nematodes are key pests of many vegetable crops (Collange et al. 2011). Methods of soil disinfestation such as chemical fumigants (Hutchinson et al. 1999), nematicides (Belair 1984), and solarization (Gamliel and Stapleton 1993) are effective for managing these nematodes but can be environmentally damaging or not conducive to temperate environmental conditions. Clubroot is a key limiting factor in the production of Brassicaceous

Current address of A. L. Testen: United States Department of AgricultureAgricultural Research Service North Central Regional Plant Introduction Station, Ames, IA, 50011.

${ }^{\dagger}$ Corresponding author: S. A. Miller; miller.769@osu.edu

Funding: This research was funded by a grant from the Ohio Vegetable and Small Fruit Research and Development Program, The Ohio State University SEEDS, and an OSU OARDC Industry Small grant. Salaries and research support were provided by state and federal funds appropriated to the Ohio Agricultural Research and Development Center, The Ohio State University.

The author(s) declare no conflict of interest.

Accepted for publication 25 February 2019.

(c) 2019 The American Phytopathological Society crops (Donald and Porter 2009). Management of clubroot currently relies on use of soil amendments to raise soil $\mathrm{pH}$, rotation with nonhost crops, and resistant varieties (McGrann et al. 2016). Soil disinfestation methods that actively decrease $P$. brassicae populations could be critical tools in integrated management of this disease.

The physical and chemical properties of muck soils hinder the effectiveness of several soilborne disease management methods. Organic matter within muck soils can bind pesticides (Harris 1972), requiring higher rates of fumigants or nematicides to achieve similar levels of root-knot nematode control compared with mineral soils (Belair 1984; Vrain et al. 1979). Higher rates of lime are needed to increase soil $\mathrm{pH}$ due to the initial low $\mathrm{pH}$ and high organic matter content, and these amendment rates may deleteriously affect nutrient availability in muck soils (Okruszko et al. 1962). The limitations of current disease management strategies highlight the need to explore alternative options for soilborne disease management in muck soils.

Anaerobic soil disinfestation (ASD) is an emerging strategy for managing soilborne diseases but ASD has not been examined as a tool for managing diseases in muck soils. Soil is first amended with a carbon source, irrigated to saturation, and covered with plastic mulch for several weeks to complete the ASD treatment (Blok et al. 2000; Momma et al. 2013). Soil redox potential is lowered by the anaerobic digestion of added carbon sources, during which toxic byproducts are produced such as organic acids and volatile organic compounds (Ebihara and Uematsu 2013; Hewavitharana et al. 2014, Momma et al. 2006). ASD is effective against a wide range of pathogens in many different cropping systems (Rosskopf et al. 2015; Strauss and Kluepfel 2015). ASD is an effective tool for managing nematode pests, including Meloidogyne spp. (Butler et al. 2012a,b; Katase et al. 2009; Lamers et al. 2010). Fewer studies have been performed to determine the efficacy of ASD against clubroot. Studies in Japan indicated that ASD using ethanol as a carbon source may be an effective method for controlling clubroot in broccoli (Shennan et al. 2014), while studies in the Netherlands indicated that $P$. brassicae survival was reduced following anaerobic digestion of $P$. brassicae-infected roots (Termorshuizen et al. 2003). 
Soilborne diseases are emerging threats to high-value specialty crop production in the Midwestern and Northeastern United States, regions that have significant areas of muck vegetable production. ASD field trials in the United States have been conducted in California, Florida, Tennessee, and Washington but, to our knowledge, there have been no published studies evaluating the efficacy of ASD in muck soils under temperate Midwestern and Northeastern production conditions. A first step to introducing ASD to a new region is to identify readily available carbon sources in the region; therefore, wheat bran and molasses were selected for this study because they are readily available at feed mills throughout the Midwest. The main objective of this study was to determine the efficacy of ASD using wheat bran- and molasses-based amendments against root-knot nematodes in lettuce and clubroot in mustard greens in high-value muck vegetable production systems. A secondary objective of this study was to evaluate the use of post-ASD bioassays as a method to quickly determine ASD field efficacy.

\section{Materials and Methods}

Research sites. Trials were initiated in June (mustard greens) and July (lettuce) 2016 and in June 2017 (both crops). The mustard greens trial was conducted at The Ohio State University Ohio Agricultural Research and Development Center Muck Crops Agricultural Research Station in Huron County, $\mathrm{OH}$ in soils naturally infested with $P$. brassicae. The lettuce trial was conducted on a commercial farm in Stark County, $\mathrm{OH}$ in muck soils naturally infested with Meloidogyne hapla. M. hapla was identified based on perineal patterns and cytochrome oxidase II sequencing (Joseph et al. 2016). Trials were conducted at a different location within each field site for each trial year. Soil properties (Spectrum Analytic Inc., Washington Courthouse, OH, U.S.A.) at each field site are described in Table 1.

Trial design. Trials were laid in a Latin square design with four replications per treatment in 2016 and five replications in 2017. This design was selected to account for potential variability in pathogen distribution in the field. Treated areas in the replicate plots were $0.91 \mathrm{~m}$ wide by $3 \mathrm{~m}$ long in both years. Treatments were separated by 6.1-m (2016) or 3-m (2017) untreated buffers within rows and 0.91-m untreated buffers between rows (both years).

ASD treatments. An uncovered, nonamended control (aerobic control, both years) representing a seasonal fallow and a covered, nonamended control (anaerobic control, 2017 only) were compared with three ASD treatments: wheat bran (ASD-WB, 20.2 $\mathrm{Mg} \mathrm{ha}^{-1}$, C:N ratio of 17; The Mennel Milling Company, Fostoria, OH, U.S.A.); molasses (ASD-MS, 10.1 $\mathrm{Mg} \mathrm{ha}^{-1}$, C:N ratio of 81, Golden Barrel blackstrap molasses; Good Food, Inc. Honey Brook, PA, U.S.A.); and wheat bran (ASD-WBM, 20.2 $\mathrm{Mg} \mathrm{ha}^{-1}$ ) combined with molasses $\left(10.1 \mathrm{Mg} \mathrm{ha}^{-1}\right)$. Amendment rates were comparable with rates used in other studies of ASD conducted in the United States (Butler et al. 2012a; Shennan et al. 2018).

Wheat bran was spread by hand and incorporated to a depth of 15 to $20 \mathrm{~cm}$ with a tractor-drawn rototiller. Molasses was diluted 1:4

Table 1. Soil properties and rainfall amounts at anaerobic soil disinfestation (ASD) trial sites in Huron and Stark Counties, OH in 2016 and 2017

\begin{tabular}{lccccc}
\hline & \multicolumn{2}{c}{ Huron } & & \multicolumn{2}{c}{ Stark } \\
\cline { 2 - 3 } \cline { 6 - 6 } Soil property & $\mathbf{2 0 1 6}$ & $\mathbf{2 0 1 7}$ & & $\mathbf{2 0 1 6}$ & $\mathbf{2 0 1 7}$ \\
\hline pH & 5.7 & 6.3 & & 5.8 & 5.8 \\
Organic matter (\%) & 20.9 & 21.4 & & 24.8 & 22.6 \\
Nitrate nitrogen (ppm) & 126 & 55 & & 85 & 30 \\
Phosphorus (ppm) & 211 & 231 & & 241 & 182 \\
Potassium (ppm) & 195 & 277 & & 152 & 146 \\
Magnesium (ppm) & 849 & 1,022 & & 767 & 659 \\
Calcium (ppm) & 5,477 & 6,391 & & 6,696 & 5,707 \\
Cation exchange capacity (meq/100 g) & 36.0 & 31.5 & & 34.2 & 34.5 \\
Rainfall during ASD treatment $(\mathrm{mm})$ & 24.1 & 154.9 & & 55.6 & 66.9 \\
Rainfall during growing season $(\mathrm{mm})^{\mathrm{z}}$ & 269.2 & 243.6 & & 195.8 & 192.0 \\
\hline
\end{tabular}

${ }^{\mathrm{y}}$ Based on $360^{\circ} \mathrm{C}$ combustion for $3 \mathrm{~h}$.

${ }^{\mathrm{z}}$ Total rainfall from start of ASD trials until harvest. with water and applied using watering cans. Plots were saturated to a depth of $20 \mathrm{~cm}$ using overhead sprinklers, and no supplemental irrigation was applied during the ASD treatment period. Soil temperatures were measured using $\mathrm{HOBO}$ pendant temperature data loggers (Onset Computer Corporation, Bourne, MA, U.S.A.), buried $15 \mathrm{~cm}$ deep in each of two plots per treatment. Reducing conditions in each plot were measured based on the loss of iron oxide paint on five 30-cm-long indicator of reduction in soils (IRIS) tubes (Rabenhorst 2008; Rabenhorst and Burch 2006) placed in each plot at the beginning of the ASD process. All plots were covered, with the exception of the uncovered control, with a $1.5-\mathrm{mm}$ embossed, black plastic mulch (PolyExpert, Inc., Laval, QC, Canada). Mulch edges were buried under soil to prevent air exchange. Plastic mulch was removed from treated areas 4 weeks following treatment application, and 10 soil samples were collected from each plot at a depth of $15 \mathrm{~cm}$ using a shovel and composited for later bioassays. IRIS tubes were removed carefully from soil at the end of the treatment, avoiding physical removal of the paint, and the percentage of paint loss on the upper and lower half of each tube was determined using the grid method (Rabenhorst 2012). Soil $\mathrm{pH}$ was determined from a 1:2 by volume soil/water mixture.

One week after plastic mulch removal, plots were direct sown with either mustard greens cultivar Southern Curled (Seedway, Hall, NY, U.S.A.) or cos lettuce cultivar Sawgrass (2016 trial; 3 Star Lettuce, Gonzales, CA, U.S.A.) or Laredo (2017 trial; Rispens Seeds Inc., Beecher, IL, U.S.A.). Supplemental overhead irrigation was only applied once following planting during the 2017 Huron trial; otherwise, the plantings relied on natural rainfall (Table 1). Mature mustard greens were harvested 46 to 48 days after seeding, and mature lettuce was harvested 56 (2016) or 69 (2017) days after seeding. Fresh aboveground biomass was recorded for both crops, and dry aboveground biomass was recorded for mustard greens only.

Post-ASD bioassay. Bioassays were conducted in a growth chamber to determine the effects of ASD on plant growth and disease. Bioassays were conducted due to regular issues with muck soil flooding and soil mixing due to the light texture of these soils. Soils from each field plot were placed in Deepots (262 ml, D16H; Steuwe and Sons, Tangent, OR, U.S.A.). Five replicate pots were used for each field plot from the experiment, which was laid out as a randomized complete block design blocked by replicate. The post-ASD bioassay was conducted twice for each crop using a subsample of soil from composite samples from the original field plots that were collected after completion of the ASD treatments. Each pot was planted with either Southern Curled mustard greens (Seedway) or lettuce cultivar Tropicana (Siegers Seed Company, Holland, MI, U.S.A.). Tropicana lettuce was selected for bioassays because it grew better under growth-chamber conditions than cos varieties. One week following emergence, mustard greens were thinned to two plants per pot, while lettuce was thinned to one plant per pot. Plants were grown in a growth chamber with a 12-h day-and-night cycle, with a daytime temperature of $25^{\circ} \mathrm{C}$ and nighttime temperature of $23^{\circ} \mathrm{C}$, and fertilized once weekly with a 20-20-20 fertilizer (Peter's Professional; ICL Fertilizers, Ltd., Beer Sheva, Israel).

Lettuce plants were grown for 9 weeks in 2016 trials and 8 weeks in 2017 trials, while mustard greens were grown for 8 weeks (2016) and 7 weeks (2017). Plants were harvested from their pots and roots were washed with tap water prior to evaluation for soilborne diseases. Wet and dry aboveground and root biomass were measured for all trials.

Disease assessment in mustard greens. The presence of $P$. bras sicae was confirmed microscopically prior to disease assessment. Clubroot severity was assessed using a 0 -to-3 scale, where $0=$ no galling, $1=$ small amount of galling, $2=$ moderate galling, and $3=$ severe galling (Strelkov et al. 2006) for 50 (2016) or 25 (2017) mustard green plants from each field plot, and these severity ratings were used to calculate a per-plot disease index (Strelkov et al. 2006). The same rating scale was used to assess roots from the post-ASD bioassay, and clubroot disease indices were calculated based on the five replicate bioassay plants produced in soil from each field plot. Root vigor, as indicated by lateral root growth, was assessed for 
field-harvested mustard green plants using a 0 -to- 3 root vigor rating scale, where $0=$ no lateral roots present; $1=$ few lateral roots, lateral roots weak; $2=$ mix of weak and strong lateral roots; and $3=$ majority of lateral roots strong, many lateral roots present. The root vigor rating was then used to determine a root vigor index using the following equation ( $n=$ number of plants with given rating): Root vigor index $=$ $\left\{\left[\sum(n \times 0+n \times 1+n \times 2+n \times 3)\right] /\right.$ number of plants $\left.\times 3\right\} \times 100$.

Disease assessment in lettuce. The presence of M. hapla was confirmed microscopically prior to disease assessment. Root-knot nematode galls were counted on root systems of 10 lettuce plants in each field plot or individual plants for bioassays. Nematode gall counts were then divided by either the fresh (field trials) or dry (bioassays) root biomass to account for differences in root size. For field plots only, gall counts were transformed using $\log _{10}$ (number of galls +1 ) to account for normality. The transformed mean value of galls per gram of root was determined for each plot and used for data analysis. Egg masses were counted on plant roots from bioassays following staining with $0.1 \%$ Phloxine B (Sigma Aldrich, St. Louis, MO, U.S.A.) (Coyne et al. 2007). For bioassays, galls or egg masses per gram root were not transformed for data analysis.

Data analysis. Data were analyzed using mixed-effects general linear models in Minitab (Minitab, Inc., State College, PA, U.S.A.), in which treatment was a fixed factor and blocking factors were random factors. Differences in means were assessed using Tukey's honestly significant difference with a family-wise error rate of $\alpha=0.05$. Data for each run of the post-ASD bioassays were combined within each crop for each trial year prior to analysis.

\section{Results}

Effect of ASD on mustard greens biomass and clubroot severity in the field. Mean 2016 soil temperatures in plots that underwent ASD were elevated compared with the aerobic control (Table 2) and varied depending on the carbon amendment (wheat bran: $+2.9^{\circ} \mathrm{C}$, molasses: $+2.6^{\circ} \mathrm{C}$, wheat bran plus molasses: $+3.9^{\circ} \mathrm{C}$ ). In 2017 trials, mean soil temperatures in amended plots (wheat bran: probe failure, molasses: +1.5 and $+0.5^{\circ} \mathrm{C}$, wheat bran plus molasses +1.7 and $+0.7^{\circ} \mathrm{C}$ ) were only slightly elevated compared with both aerobic and anaerobic control plots, respectively (Table 2). More rainfall occurred during the ASD treatment period in the 2017 trial compared with the 2016 trial (Table 1).

Anaerobic soil disinfestation treatments did not affect soil $\mathrm{pH}$ at the Huron site. Significant differences in soil $\mathrm{pH}$ were not observed following ASD treatments for either trial year (2016: $P=0.2$ and 2017: $P=0.5)($ Table 2).

Soil reducing conditions, as indicated by the percentage of iron oxide paint lost from IRIS tubes, were significantly greater (both years: $P<0.0001)$ in ASD-WB or ASD-WBM soils compared with ASDMS plots and nonamended controls following ASD treatment for both trial years (Table 3). Overall reducing conditions indicated by

Table 2. Mean soil temperatures during anaerobic soil disinfestation (ASD) with one of three carbon sources-wheat bran (ASD-WB), molasses (ASDMS), or wheat bran plus molasses (ASD-WBM) - and soil $\mathrm{pH}$ following treatment of muck soils in Huron and Stark Counties, OH in 2016 and 2017y

\begin{tabular}{|c|c|c|c|c|c|c|c|c|}
\hline \multirow[b]{3}{*}{ Treatment } & \multicolumn{4}{|c|}{ Temperature $\left({ }^{\circ} \mathrm{C}\right)$} & \multicolumn{4}{|c|}{ pH } \\
\hline & \multicolumn{2}{|c|}{ Huron } & \multicolumn{2}{|c|}{ Stark } & \multicolumn{2}{|c|}{ Huron } & \multicolumn{2}{|c|}{ Stark } \\
\hline & 2016 & 2017 & 2016 & 2017 & 2016 & 2017 & 2016 & 2017 \\
\hline ASD-WB & 27.3 & ND & 30.8 & 27.1 & 5.6 & 6.3 & $5.5 \mathrm{~b}$ & $5.3 \mathrm{~d}$ \\
\hline ASD-MS & 27.0 & 25.1 & 29.7 & 26.2 & 5.8 & 6.3 & $5.8 \mathrm{a}$ & $5.7 \mathrm{ab}$ \\
\hline ASD-WBM & 28.3 & 25.3 & ND & 27.7 & 5.6 & 6.4 & $5.5 \mathrm{~b}$ & $5.5 \mathrm{c}$ \\
\hline $\begin{array}{l}\text { Aerobic } \\
\text { control }\end{array}$ & 24.4 & 23.6 & 24.5 & 23.1 & 5.7 & 6.4 & $5.9 \mathrm{a}$ & $5.8 \mathrm{a}$ \\
\hline $\begin{array}{l}\text { Anaerobic } \\
\text { control }\end{array}$ & $\cdots$ & 24.6 & $\ldots$ & 24.9 & $\cdots$ & 6.4 & $\cdots$ & $5.7 \mathrm{~b}$ \\
\hline$P$ value ${ }^{\mathrm{z}}$ & N/A & N/A & N/A & N/A & 0.2 & 0.5 & $<0.0001$ & $<0.0001$ \\
\hline
\end{tabular}

y Mean values in a column sharing the same letter do not differ significantly at $\alpha=0.05 . \mathrm{ND}=$ no data due to probe failure and N/A = not applicable.

${ }^{\mathrm{z}}$ Analysis of variance $P$ value for treatment effect. loss of iron oxide paint were significantly greater in ASD-MS plots in 2017 only compared with nonamended plots (Table 3).

Following the 2016 field trial, the dry biomass of mustard greens grown in any ASD-treated plot did not differ significantly from the biomass of mustard greens grown in nonamended, control plots $(P=0.03)$ (Table 4). In contrast, following the 2017 trial, significantly higher dry biomass was observed for mustard greens grown in ASD-WB or ASD-WBM plots than in mustard greens grown in ASD-MS or control plots $(P<0.0001)$ (Table 4$)$.

Clubroot disease indices in the 2016 field trial did not differ significantly $(P=0.2)$ among mustard greens from plots amended with different carbon sources and treated with ASD but disease indices from plants removed from all ASD-treated plots trended lower than those in nonamended control plots (Table 4). Disease indices of plants in the anaerobic and aerobic controls did not differ in 2017, when the anaerobic control was added to the trial. In 2017 trials, the mean clubroot disease index was significantly lower $(P=0.004)$ in mustard greens grown in ASD-WBM plots compared with disease indices of plants grown in plots of either control (Table 4). A significantly lower clubroot disease index was also observed in mustard greens grown in ASD-WB plots compared with plants grown in aerobic control plots. The clubroot disease index of mustard greens grown in ASD-MS plots did not differ significantly compared with plants grown in plots of any other treatment in 2017 (Table 4).

Root vigor was affected by ASD treatment in both years (2016: $P=$ 0.007 and 2017: $P=0.002$ ) (Table 4). Significantly higher root vigor indices were observed in mustard greens grown in ASD-WB and ASD-MS plots compared with plants from aerobic control plots in the 2016 field trials (Table 4). In the 2017 field trial, significantly higher root vigor was observed for mustard greens grown in

Table 3. Percentage of iron oxide paint loss on indicator of reduction in soils (IRIS) tubes placed in anaerobic soil disinfestation (ASD) trial plots amended with one of three carbon sources-wheat bran (ASD-WB), molasses (ASDMS), or wheat bran plus molasses (ASD-WBM) - in Huron and Stark Counties, $\mathrm{OH}$ in 2016 and $2017^{\mathrm{y}}$

\begin{tabular}{lccccr}
\hline & \multicolumn{2}{c}{ Huron } & & \multicolumn{2}{c}{ Stark } \\
\cline { 2 - 3 } \cline { 5 - 6 } Treatment & $\mathbf{2 0 1 6}$ & $\mathbf{2 0 1 7}$ & & $\mathbf{2 0 1 6}$ & $\mathbf{2 0 1 7}$ \\
\hline ASD-WB & $29.4 \mathrm{a}$ & $57.7 \mathrm{a}$ & & $24.5 \mathrm{a}$ & $15.5 \mathrm{a}$ \\
ASD-MS & $6.8 \mathrm{~b}$ & $43.6 \mathrm{~b}$ & & $2.2 \mathrm{c}$ & $7.0 \mathrm{~b}$ \\
ASD-WBM & $32.3 \mathrm{a}$ & $65.3 \mathrm{a}$ & & $15.1 \mathrm{~b}$ & $14.3 \mathrm{a}$ \\
Aerobic control & $0.0 \mathrm{~b}$ & $0.1 \mathrm{c}$ & & $0.1 \mathrm{c}$ & $0.1 \mathrm{c}$ \\
Anaerobic control & $\ldots$ & $0.9 \mathrm{c}$ & & $\ldots$ & $0.4 \mathrm{c}$ \\
$P$ value $^{\mathrm{z}}$ & $<0.0001$ & $<0.0001$ & & $<0.0001$ & $<0.0001$
\end{tabular}

${ }^{y}$ Mean values in a column sharing the same letter do not differ significantly at $\alpha=0.05$

${ }^{\mathrm{z}}$ Analysis of variance $P$ value for treatment effect

Table 4. Aboveground plant biomass, clubroot disease index, and root vigor of mustard green plants following anaerobic soil disinfestation (ASD) with one of three carbon sources-wheat bran (ASD-WB), molasses (ASD-MS), or wheat bran plus molasses (ASD-WBM) - in field trials in Huron County, $\mathrm{OH}$ in 2016 and $2017^{\mathrm{w}}$

\begin{tabular}{|c|c|c|c|c|c|c|}
\hline \multirow[b]{2}{*}{ Treatment } & \multicolumn{2}{|c|}{$\operatorname{Biomass}(\mathbf{g})^{\mathbf{x}}$} & \multicolumn{2}{|c|}{ Disease index ${ }^{y}$} & \multicolumn{2}{|c|}{$\begin{array}{l}\text { Root vigor } \\
\text { index }\end{array}$} \\
\hline & 2016 & 2017 & 2016 & 2017 & 2016 & 2017 \\
\hline ASD-WB & $316.0 \mathrm{a}$ & $121.2 \mathrm{a}$ & 21.8 & $25.3 \mathrm{bc}$ & $80.7 \mathrm{a}$ & $79.2 \mathrm{a}$ \\
\hline ASD-MS & $268.0 \mathrm{~b}$ & $51.5 \mathrm{~b}$ & 27.3 & $33.6 \mathrm{abc}$ & $76.0 \mathrm{ab}$ & $74.1 \mathrm{ab}$ \\
\hline ASD-WBM & $305.4 \mathrm{ab}$ & $141.8 \mathrm{a}$ & 28.8 & $22.4 \mathrm{c}$ & $72.0 \mathrm{bc}$ & $80.8 \mathrm{a}$ \\
\hline Aerobic control & $309.9 \mathrm{ab}$ & $59.9 \mathrm{~b}$ & 35.3 & $43.2 \mathrm{a}$ & $66.8 \mathrm{c}$ & $59.8 \mathrm{~b}$ \\
\hline Anaerobic control & $\ldots$ & $63.9 \mathrm{~b}$ & $\ldots$ & $39.2 \mathrm{ab}$ & $\ldots$ & $61.9 \mathrm{~b}$ \\
\hline$P$ value $\mathrm{z}$ & 0.03 & $<0.0001$ & 0.2 & 0.004 & 0.007 & 0.002 \\
\hline
\end{tabular}

${ }^{\mathrm{w}}$ Mean values in a column sharing the same letter do not differ significantly at $\alpha=0.05$.

x Dry aboveground biomass per 50 (2016) or 25 (2017) plants.

y Percent disease index (Strelkov et al. 2006).

z Analysis of variance $P$ value for treatment effect. 
ASD-WB or ASD-WBM plots compared with plants grown in plots of either nonamended control (Table 4).

Mustard greens post-ASD bioassays. The dry aboveground biomass of mustard greens grown in soils collected from ASD-WB or ASD-WBM plots was significantly higher than the biomass of plants grown in soils collected from control plots for both trial years (both years: $P<0.0001)$ (Table 5). For soils collected during the 2016 field trial, significantly lower clubroot disease indices $(P<0.0001)$ were observed in plants grown in soils collected from plots treated with any ASD amendment compared with the disease index of plants grown in soil collected from the aerobic control plot. For the 2017 bioassay, disease indices of plants grown in soils collected from ASD-MS or ASD-WBM plots were significantly lower $(P=0.005)$ than for plants grown in soils collected from the aerobic control only. Disease indices of plants grown in soils collected from ASD-WB plots or the anaerobic control did not differ significantly from plants grown in soils from any other plots (Table 5).

Effect of ASD on lettuce biomass and root-knot nematode severity in the field. Mean 2016 soil temperatures in ASD-treated plots (wheat bran: $+6.3^{\circ} \mathrm{C}$, molasses: $+5.2^{\circ} \mathrm{C}$, wheat bran plus molasses: probe failure) were elevated compared with those in nonamended control plots (Table 2). Similar temperature increases were observed in ASD-treated plots in 2017 (wheat bran: +4 and $+2.2^{\circ} \mathrm{C}$, molasses: +3.1 and $+1.3^{\circ} \mathrm{C}$, wheat bran plus molasses: 4.6 and $+2.8^{\circ} \mathrm{C}$ ) compared with mean soil temperatures in both aerobic and anaerobic control plots, respectively (Table 2). Rainfall amounts during the ASD treatment period were comparable in both trial years (Table 1).

In both trial years, soil $\mathrm{pH}$ decreased significantly (both years: $P<$ 0.0001) during ASD in ASD-WB or ASD-WBM plots compared with ASD-MS and nonamended plots (Table 2). The pH of ASDMS plots did not differ significantly from control plots in either trial year.

Significantly higher levels (both years: $P<0.0001$ ) of iron oxide paint loss were observed on IRIS tubes placed in ASD-WB or ASDWBM plots compared with IRIS tubes placed in ASD-MS and nonamended plots for both trial years (Table 3). Similar to the trials in Huron County, significantly higher amounts of iron oxide paint were lost on IRIS tubes placed in ASD-MS plots compared with control plots during the 2017 trials only.

ASD treatments did not have a consistent influence on lettuce biomass (both years: $P=0.03$ ) (Table 6). Following ASD treatment in 2016, fresh biomass was significantly higher in ASD-WBM plots compared with lettuce from the aerobic control (Table 6). However, in 2017, the biomass of lettuce grown in ASD-WBM plots was significantly higher than the biomass of lettuce grown in anaerobic control plots but the biomass of plants grown in these ASD-WBM plots did not differ significantly from that of plants in the aerobic control plots (Table 6). Significant differences in lettuce biomass were not observed for ASD-MS or ASD-WB plots compared with that of lettuce grown in either type of control in either year.

Table 5. Aboveground plant biomass and clubroot disease index of mustard greens grown in bioassays using soils collected from field plots treated with anaerobic soil disinfestation (ASD) with one of three carbon sources-wheat bran (ASD-WB), molasses (ASD-MS), or wheat bran plus molasses (ASDWBM) - in Huron County, OH in 2016 and 2017w

\begin{tabular}{|c|c|c|c|c|}
\hline \multirow[b]{2}{*}{ Treatment } & \multicolumn{2}{|c|}{ Biomass $(g)^{x}$} & \multicolumn{2}{|c|}{ Disease index ${ }^{y}$} \\
\hline & 2016 & 2017 & 2016 & 2017 \\
\hline ASD-WB & $1.4 \mathrm{ab}$ & $1.6 \mathrm{~b}$ & $1.7 \mathrm{~b}$ & $22.7 \mathrm{ab}$ \\
\hline ASD-MS & $1.1 \mathrm{bc}$ & $1.1 \mathrm{c}$ & $7.9 \mathrm{~b}$ & $17.8 \mathrm{~b}$ \\
\hline ASD-WBM & $1.6 \mathrm{a}$ & $2.0 \mathrm{a}$ & $11.7 \mathrm{~b}$ & $14.7 \mathrm{~b}$ \\
\hline Aerobic control & $0.9 \mathrm{c}$ & $0.9 \mathrm{c}$ & $56.0 \mathrm{a}$ & $45.5 \mathrm{a}$ \\
\hline Anaerobic control & $\ldots$ & $0.8 \mathrm{c}$ & $\ldots$ & $29.0 \mathrm{ab}$ \\
\hline$P$ value ${ }^{\mathrm{z}}$ & $<0.0001$ & $<0.0001$ & $<0.0001$ & 0.005 \\
\hline
\end{tabular}

During the 2016 trial year, root-knot nematode galling was significantly lower $(P=0.006)$ in lettuce grown in plots treated with any ASD carbon source compared with plants grown in aerobic control plots (Table 6). In 2017, significantly fewer galls $(P=0.004)$ were observed on lettuce grown in either ASD-WB or ASD-WBM plots compared with plants grown in either anaerobic or aerobic control plots. Lettuce grown in ASD-MS plots did not have significantly lower levels of root-knot nematode galling compared with lettuce grown in plots of either control in 2017. Root-knot galling severity was similar in lettuce plants grown in the aerobic and nonaerobic controls.

Lettuce post-ASD bioassays. In both years' bioassays, significantly higher biomass (both years: $P<0.0001$ ) was observed for lettuce grown in soils from field ASD-WB or ASD-WBM plots compared with ASD-MS or nonamended, control plots (Table 7). In both years' bioassays, significantly fewer galls per gram of root (both years: $P<0.0001$ ) were observed on plants grown in soils collected from any ASD-treated plot compared with plants grown in soils collected from either control plot. Root-knot nematode galling did not differ significantly between ASD treatments for either year's bioassay. ASD treatments also reduced the number of egg masses present on root systems (both years: $P<0.0001$ ). For the 2016 bioassay, significantly fewer egg masses were present on lettuce grown in soils collected from any ASD treatment compared with plants grown in soils from aerobic control plots. For the 2017 bioassay,

Table 6. Aboveground plant biomass and nematode damage of lettuce plants following anaerobic soil disinfestation (ASD) trials with one of three carbon sources - wheat bran (ASD-WB), molasses (ASD-MS), or wheat bran plus molasses (ASD-WBM) —in Stark County, OH in 2016 and 2017w

\begin{tabular}{lccccc}
\hline & \multicolumn{2}{c}{ Biomass $(\mathbf{k g})^{\mathbf{x}}$} & & \multicolumn{2}{c}{$\begin{array}{c}\text { Galls per gram of } \\
\text { Treot }\end{array}$} \\
\cline { 2 - 3 } \cline { 6 - 7 } Treatment & $\mathbf{2 0 1 6}$ & $\mathbf{2 0 1 7}$ & & $\mathbf{2 0 1 6}$ & $\mathbf{2 0 1 7}$ \\
\hline ASD-WB & $0.47 \mathrm{ab}$ & $0.91 \mathrm{ab}$ & & $0.3 \mathrm{~b}$ & $0.01 \mathrm{~b}$ \\
ASD-MS & $0.40 \mathrm{ab}$ & $0.88 \mathrm{ab}$ & & $0.5 \mathrm{~b}$ & $0.03 \mathrm{ab}$ \\
ASD-WBM & $0.51 \mathrm{a}$ & $1.05 \mathrm{a}$ & & $0.3 \mathrm{~b}$ & $0.01 \mathrm{~b}$ \\
Aerobic control & $0.38 \mathrm{~b}$ & $0.93 \mathrm{ab}$ & & $1.9 \mathrm{a}$ & $0.07 \mathrm{a}$ \\
Anaerobic control & $\ldots$ & $0.73 \mathrm{~b}$ & & $\ldots$ & $0.09 \mathrm{a}$ \\
$P$ value $^{\mathrm{z}}$ & 0.03 & 0.03 & & 0.006 & 0.004 \\
\hline
\end{tabular}

${ }^{\mathrm{w}}$ Mean values in a column sharing the same letter do not differ significantly at $\alpha=0.05$.

${ }^{x}$ Fresh biomass per plant.

y Raw values of galls per gram fresh root. To account for normality, data analysis was performed on $\left[\log _{10}(\right.$ number of galls +1$) /$ fresh root biomass $\left.(\mathrm{g})\right]$. z Analysis of variance $P$ value for treatment effect.

Table 7. Aboveground plant biomass and root-knot nematode galling and egg production on lettuce plants grown in bioassays using soils collected from field plots treated with anaerobic soil disinfestation (ASD) with one of three carbon sources - wheat bran (ASD-WB), molasses (ASD-MS), or wheat bran plus molasses (ASD-WBM)—in Stark County, OH in 2016 and 2017w

\begin{tabular}{|c|c|c|c|c|c|c|}
\hline \multirow[b]{2}{*}{ Treatment } & \multicolumn{2}{|c|}{$\operatorname{Biomass}(g)^{x}$} & \multicolumn{2}{|c|}{$\begin{array}{l}\text { Galls per gram of } \\
\text { root }^{y}\end{array}$} & \multicolumn{2}{|c|}{$\begin{array}{l}\text { Egg masses per } \\
\text { gram of rooty }\end{array}$} \\
\hline & 2016 & 2017 & 2016 & 2017 & 2016 & 2017 \\
\hline ASD-WB & $5.1 \mathrm{a}$ & $5.0 \mathrm{a}$ & $13.2 \mathrm{~b}$ & $0.5 \mathrm{~b}$ & $2.3 \mathrm{~b}$ & $0.2 \mathrm{c}$ \\
\hline ASD-MS & $3.0 \mathrm{~b}$ & $2.7 \mathrm{~b}$ & $63.3 \mathrm{~b}$ & $15.7 \mathrm{~b}$ & $10.5 \mathrm{~b}$ & $6.3 \mathrm{bc}$ \\
\hline ASD-WBM & $4.6 \mathrm{a}$ & $4.5 \mathrm{a}$ & $1.4 \mathrm{~b}$ & $0.7 \mathrm{~b}$ & $0.3 \mathrm{~b}$ & $0.2 \mathrm{c}$ \\
\hline $\begin{array}{l}\text { Aerobic } \\
\text { control }\end{array}$ & $1.3 \mathrm{c}$ & $2.2 \mathrm{~b}$ & $285.9 \mathrm{a}$ & & 88.6 a & $16.9 \mathrm{a}$ \\
\hline $\begin{array}{c}\text { Anaerobic } \\
\text { control }\end{array}$ & $\ldots$ & $2.3 \mathrm{~b}$ & $\ldots$ & $70.9 \mathrm{a}$ & $\cdots$ & $12.1 \mathrm{ab}$ \\
\hline$P$ value $^{\mathrm{z}}$ & $<0.0001$ & $<0.0001$ & $<0.0001$ & $<0.0001$ & $<0.0001$ & $<0.0001$ \\
\hline
\end{tabular}


significantly fewer egg masses were present on lettuce grown in soils collected from either ASD-WB or ASD-WBM plots compared with lettuce grown in soils from plots of either control. Significantly fewer egg masses per gram of root were observed for lettuce grown in soils from ASD-MS plots compared with lettuce grown in aerobic but not anaerobic control soils.

\section{Discussion}

Muck soils present particular challenges to the management of soilborne diseases by traditional, chemical-based approaches. We evaluated the efficacy of ASD with readily available carbon sources as a means to control key, difficult-to-manage soilborne diseases in high-value muck vegetable production systems. We used field trials followed by post-ASD bioassays to determine the impacts of ASD on root-knot nematode severity and reproduction and clubroot disease severity.

The experimental design used in this project allowed for the rapid determination of differences in treatments that may be missed due to flooding or soil mixing that may have occurred during the growing season due to small plot size. The clubroot disease index trended lower in mustard greens from ASD-treated field plots in 2016 but the differences were not significant. In 2017, the clubroot disease index was significantly lower for mustard greens from ASD-WBM plots than for plants from both the anaerobic and aerobic controls. However, significant decreases in disease indices were observed in post-ASD bioassays using soil collected from plots immediately after plastic mulch removal in both years, which may indicate contamination of ASD-treated plots by nonamended soil in the field by tillage following mulch removal or movement of inoculum among plots as a result of rainfall activity. Plot sizes in these trials were selected based on the bed width used in each cropping system, which may have enabled inoculum mixing from nearby nontreated plots during periods of intense rainfall. Future studies should be performed to quantify $P$. brassicae soil populations following ASD using quantitative polymerase chain reaction paired with propidium monoazide to account for spore viability (Al-Daoud et al. 2017) to assess impacts of ASD on $P$. brassicae survival.

Anaerobic soil disinfestation was effective in reducing nematode damage in lettuce grown on muck soils in on-farm trials, supporting previous findings that ASD is an effective tool for reducing root-knot damage (Butler et al. 2012a,b; Katase et al. 2009). Consistent reductions were obtained with ASD-WB and ASD-WBM in both trial years compared with use of ASD-MS, which led to significant reductions in galling in the field during one trial year only. Soil reducing conditions, as indicated by IRIS tubes, were less intense in ASDMS plots in the lettuce trials, and decreases in soil $\mathrm{pH}$ were not observed in these ASD-MS plots as in the ASD-WB or ASD-WBM plots. The limited reducing conditions and lack of $\mathrm{pH}$ decrease could indicate some other mechanism of nematode reduction aside from anaerobic conditions (Ebihara and Uematsu 2013) or the production of organic acids (Katase et al. 2009), which are often proposed as key mechanisms of ASD. Soil applications of molasses alone, comparable with the rates used in these studies, have been shown to reduce root-knot nematode galling and soil populations in tomato (Vawdrey and Stirling 1997) and squash (Rodriguez-Kabana and King 1980). A solarization effect can contribute to root-knot suppression observed due to the mulch covering in all ASD treatments if soil temperatures are high enough during treatment. However, in this study, the maximum temperature in any plot, $39.6^{\circ} \mathrm{C}$ in an ASDWB plot, was not sustained for a long period of time and is below reported field solarization temperatures in other studies on Meloidogyne spp. (Gamliel and Stapleton 1993; Wang and McSorley 2008). The maximum soil temperature in ASD-MS plots was $36^{\circ} \mathrm{C}$, a temperature below that needed to kill $M$. incognita juveniles based on laboratory experiments (Wang and McSorley 2008).

The carbon sources used in this project were selected because they were readily available to Midwestern growers and have proven efficacy in previous ASD studies (Butler et al. 2012a; McCarty et al. 2014; Momma et al. 2006; Yossen et al. 2008). Use of ASD on muck soils is currently quite costly but further research could help reduce costs by finding alternative carbon sources and their lowest effective rates. Based on December 2018 pricing at a local Ohio feed mill, wheat bran would cost approximately $\$ 3,450$ per acre and molasses would cost $\$ 1,490$ per acre. These costs could be reduced by using comparable but less expensive alternatives such as wheat midds $(\$ 2,180$ per acre) or by treating only beds prior to planting. Amendment rates were selected based on comparable studies in the United States but further studies are required to identify the lowest effective rates of these carbon sources on muck soils. Other carbon sources such as those higher in protein (Meints and Feil 2017; Runia et al. 2014) may have improved efficacy for controlling the target pathogens on muck soils. Cover crops could be a viable option as an alternative or supplemental ASD carbon source because cover crops such as rye are already incorporated into muck crop vegetable production to reduce erosion. Cover crops have been examined in ASD studies (Butler et al. 2012b; Hewavitharana et al. 2014) but their efficacy has yet to be determined in muck soil systems. Cover crops could be used as trap crops grown in situ prior to ASD to stimulate germination of P. brassicae resting spores (Friberg et al. 2006) or draw root-knot nematodes toward the soil surface (Kokalis-Burelle et al. 2013). Cash crops such as arugula could also act as trap crops for Meloidogyne spp. (Xu et al. 2006) and may be more economically feasible than cover crops in rotations immediately preceding ASD treatments.

Muck soil production systems differ from other vegetable production systems in which ASD has been tested previously, and these differences must be taken into consideration when integrating ASD into disease management plans for muck soils. Muck soil systems do not rely on plasticulture as in many other vegetable production systems. The lack of established plasticulture practices is a key limitation to the adoption of ASD in muck soil production systems, because ASD is dependent on soil tarping. Another constraint to the effectiveness of ASD in muck soils is the mobility of soilborne pathogen propagules due to soil movement by water or wind. Muck soils tend to flood frequently because they are wetland derived and often low lying. $P$. brassicae propagules can move easily in flooded fields (Dixon 2009), as can nematodes and other important pathogens, including Phytophthora capsici (Lewis Ivey and Miller 2013). The light texture of muck soils make them prone to wind erosion (Zobeck et al. 2013), which can also disseminate Plasmodiophora brassicae spores (Dixon 2009) over large distances. Reintroduction of pathogens through the use of contaminated surface water for irrigation would also limit the usefulness of ASD or any other soil disinfestation approach.

The results of our trials indicate that ASD is a promising option for managing soilborne diseases in high-value muck soil vegetable production systems. There are several factors that need to be considered to foster widespread farmer adoption in muck production systems, including additional effective carbon sources and rates, optimal timing within the cropping cycle, length of the tarping period, water delivery methods to avoid spreading pathogens, and a better understanding of the persistence of suppressive effects over time.

\section{Acknowledgments}

We thank our grower collaborators for their time and expertise; B. Filbrun, R. Khadka, J. Mera, M. Moodispaw, P. Paul, H. Perez, N. Rehm, C. SaintPreux, A. Sanabria, and C. Vrisman for assistance in the field; and the anonymous reviewers for their useful comments for improving our manuscript.

\section{Literature Cited}

Al-Daoud, F., Gossen, B. D., Robson, J., and McDonald, M. R. 2017. Propidium monoazide improves quantification of resting spores of Plasmodiophora brassicae with qPCR. Plant Dis. 101:442-447.

Belair, G. 1984. Nonfumigant nematicides for control of Northern root-knot nematode in muck-grown carrots. Can. J. Plant Sci. 64:175-179.

Blok, W. J., Lamers, J. G., Termorshuizen, A. J., and Bollen, G. J. 2000. Control of soilborne plant pathogens by incorporating fresh organic amendments followed by tarping. Phytopathology 90:253-259.

Butler, D. M., Kokalis-Burelle, N., Muramoto, J., Shennan, C., McCollum, T. G., and Rosskopf, E. N. 2012a. Impact of anaerobic soil disinfestation combined with soil solarization on plant-parasitic nematodes and introduced inoculum of soilborne plant pathogens in raised-bed vegetable production. Crop Prot $39: 33-40$. 
Butler, D. M., Rosskopf, E. N., Kokalis-Burelle, N., Albano, J. P., Muramoto, J., and Shennan, C. 2012b. Exploring warm-season cover crops as carbon sources for anaerobic soil disinfestation (ASD). Plant Soil 355:149-165.

Collange, B., Navarrete, M., Peyre, G., Mateille, T., and Tchamitchian, M. 2011. Root-knot nematode (Meloidogyne) management in vegetable crop production: The challenge of an agronomic system analysis. Crop Prot. 30:1251-1262.

Coyne, D. L., Nicol, J. M., and Claudius-Cole, B. 2007. Practical Plant Nematology: A Field and Laboratory Guide. IITA, Contonou, Benin.

Dixon, G. R. 2009. Plasmodiophora brassicae in its environment. J. Plant Growth Regul. 28:212-228.

Donald, C., and Porter, I. 2009. Integrated control of clubroot. J. Plant Growth Regul. 28:289-303.

Ebihara, Y., and Uematsu, S. 2013. Survival of strawberry-pathogenic fungi Fusarium oxysporum f. sp. fragariae, Phytophthora cactorum and Verticillium dahliae under anaerobic conditions. J. Gen. Plant Pathol. 80:50-58.

Friberg, H., Lagerlöf, J., and Rämert, B. 2006. Usefulness of nonhost plants in managing Plasmodiophora brassicae. Plant Pathol. 55:690-695.

Gamliel, A., and Stapleton, J. J. 1993. Effect of chicken compost or ammonium phosphate and solarization on pathogen control, rhizosphere microorganisms, and lettuce growth. Plant Dis. 77:886-891.

Harris, C. R. 1972. Factors influencing the effectiveness of soil insecticides. Annu. Rev. Entomol. 17:177-198.

Hewavitharana, S. S., Ruddell, D., and Mazzola, M. 2014. Carbon sourcedependent antifungal and nematicidal volatiles derived during anaerobic soil disinfestation. Eur. J. Plant Pathol. 140:39-52.

Hutchinson, C. M., McGiffen, M. E., Ohr, H. D., Sims, J. J., and Becker, J. O. 1999. Evaluation of methyl iodide as a soil fumigant for root-knot nematode control in carrot production. Plant Dis. 83:33-36.

Joseph, S., Mekete, T., Danquah, W., and Noling, J. 2016. First report of Meloidogyne haplanaria infecting Mi-resistant tomato plants in Florida and its molecular diagnosis based on mitochondrial haplotype. Plant Dis. 100: 1438-1445.

Katase, M., Kubo, C., Ushio, S., Ootsuka, E., Takeuchi, T., and Mizukubo, T. 2009. Nematicidal activity of volatile fatty acids generated from wheat bran in reductive soil disinfestation. Jpn. J. Nematol. 39:53-62.

Kokalis-Burelle, N., Butler, D. M., and Rosskopf, E. N. 2013. Evaluation of cover crops with potential for use in anaerobic soil disinfestation (ASD) for susceptibility to three species of Meloidogyne. J. Nematol. 45:272-278.

Lamers, J. G., Runia, W. T., Molendijk, L. P. G., and Bleeker, P. O. 2010. Perspectives of anaerobic soil disinfestation. Acta Hortic. 883:277-283.

Lewis Ivey, M. L., and Miller, S. A. 2013. Assessing the efficacy of pre-harvest, chlorine-based sanitizers against human pathogen indicator microorganisms and Phytophthora capsici in non-recycled surface irrigation water. Water Res. 47:4639-4651.

McCarty, D. G., Inwood, S. E., Ownley, B. H., Sams, C. E., Wszelaki, A. L., and Butler, D. M. 2014. Field evaluation of carbon sources for anaerobic soil disinfestation in tomato and bell pepper production in Tennessee. HortScience 49:272-280.

McGrann, G. R. D., Gladders, P., Smith, J. A., and Burnett, F. 2016. Control of clubroot (Plasmodiophora brassicae) in oilseed rape using varietal resistance and soil amendments. Field Crops Res. 186:146-156.

Meints, H., and Feil, H. 2017. Method of biological soil decontamination. European Patent 2352602.

Momma, N., Kobara, Y., Uematsu, S., Kita, N., and Shinmura, A. 2013. Development of biological soil disinfestations in Japan. Appl. Microbiol. Biotechnol. 97:3801-3809.

Momma, N., Yamamoto, K., Simandi, P., and Shishido, M. 2006. Role of organic acids in the mechanisms of biological soil disinfestation (BSD). J. Gen. Plant Pathol. 72:247-252.
Okruszko, H., Warren, G. F., and Wilcox, G. E. 1962. Influence of calcium on phosphorus availability in muck soil. Soil Sci. Soc. Am. J. 26:68-71

Rabenhorst, M. C. 2008. Protocol for using and interpreting IRIS tubes. Soil Surv. Horiz. 49:74-77.

Rabenhorst, M. C. 2012. Simple and reliable approach for quantifying IRIS tube data. Soil Sci. Soc. Am. J. 76:307-308.

Rabenhorst, M. C., and Burch, S. N. 2006. Synthetic iron oxides as an indicator of reduction in soils (IRIS). Soil Sci. Soc. Am. J. 70:1227-1236.

Rodriguez-Kabana, R., and King, P. S. 1980. Use of mixtures of urea and blackstrap molasses for control of root-knot nematodes in soils. Nematropica 10:38-44.

Rosskopf, E. N., Serrano-Pérez, P., Hong, J., Shrestha, U., Rodríguez-Molina, M., Martin, K., Kokalis-Burelle, N., Shennan, C., Muramoto, J., and Butler, D. 2015. Anaerobic soil disinfestation and soilborne pest management. Pages 277-305 in: Organic Amendments and Soil Suppressiveness in Plant Disease Management. M. K. Meghvansi and A. Varma, eds. Springer International Publishing, New York, NY, U.S.A.

Runia, W., Thoden, T., Molendijk, L., van den Berg, W., Termorshuizen, A. Streminska, M., van der Wurff, A., Feil, H., and Meints, H. 2014 Unravelling the mechanism of pathogen inactivation during anaerobic soil disinfestation. Pages 177-193 in: VIII Int. Symp. Chem. Nonchem. Soil Substrate Disinfest., Vol. 1044, Torino, Italy.

Shennan, C., Muramoto, J., Koike, S., Baird, G., Fennimore, S., Samtani, J., Bolda, M., Dara, S., Daugovish, O., Lazarovits, G., Butler, D., Rosskopf, E., KokalisBurrelle, N., Klonsky, K., and Mazzola, M. 2018. Anaerobic soil disinfestation is an alternative to soil fumigation for control of some soilborne pathogens in strawberry production. Plant Pathol. 67:51-66.

Shennan, C., Muramoto, J., Lamers, J., Mazzola, M., Rosskopf, E. N., KokalisBurelle, N., Momma, N., Butler, D. M., and Kobara, Y. 2014. Anaerobic soil disinfestation for soil borne disease control in strawberry and vegetable systems: Current knowledge and future directions. Acta Hortic. 1044:165-175.

Strauss, S. L., and Kluepfel, D. A. 2015. Anaerobic soil disinfestation: A chemicalindependent approach to pre-plant control of plant pathogens. J. Integr. Agric. 14:2309-2318.

Strelkov, S. E., Tewari, J. P., and Smith-Degenhardt, E. 2006. Characterization of Plasmodiophora brassicae populations from Alberta, Canada. Can. J. Plant Pathol. 28:467-474.

Termorshuizen, A. J., Volker, D., Blok, W. J., Brummeler, E., Hartog, B. J., Janse, J. D., Knol, W., and Wenneker, M. 2003. Survival of human and plant pathogens during anaerobic mesophilic digestion of vegetable, fruit, and garden waste. Eur. J. Soil Biol. 39:165-171.

Vawdrey, L. L., and Stirling, G. R. 1997. Control of root-knot nematode (Meloidogyne javanica) on tomato with molasses and other organic amendments. Australas. Plant Pathol. 26:179-187.

Vrain, T. C., Belair, G., and Martel, P. 1979. Nonfumigant nematicides for control of root-knot nematode to protect carrot root growth in organic soils. J. Nematol. 11:328-333.

Wang, K. H., and McSorley, R. 2008. Exposure time to lethal temperatures for Meloidogyne incognita suppression and its implication for soil solarization. J. Nematol. 40:7-12.

Xu, A., Melakeberhan, H., Mennan, S., Kravchenko, A., and Riga, E. 2006. Potential use of arugula (Eruca sativa L.) as a trap crop for Meloidogyne hapla. Nematology 8:793-799.

Yossen, V., Zumelzu, G., Gasoni, L., and Kobayashi, K. 2008. Effect of soil reductive sterilisation on Fusarium wilt in greenhouse carnation in Córdoba, Argentina. Australas. Plant Pathol. 37:520-522.

Zobeck, T. M., Baddock, M., Van Pelt, R. S., Tatarko, J., and Acosta-Martinez, V. 2013. Soil property effects on wind erosion of organic soils. Aeolian Res. 10: $43-51$. 